\title{
Gamification Thinking: Clues for New Generation Staff Management
}

\author{
Sujuan $\mathrm{Zhao}^{1}$, Xiuli $\mathrm{Li}^{1}$ \\ ${ }^{1}$ Hebei Normal University of Science and Technology, Qinhuangdao, 066004, China
}

Keywords: new generation; gamification thinking; management

\begin{abstract}
Many management modes which has been proved successfully face great challenge while they meet new generation staff; they are just like iron-crown spell with fault and have slight effect, and even cause misfortune. The enterprise managers shall change the way of thinking, liberate their thoughts, blend symbol system related to games into "non-game" management field, and explore clues for new generation staff management from a brand-new perspective.
\end{abstract}

\section{Introduction}

The so-called new generation refers to post-85s and post-90s; they neither have the post-60s' view of glorious labor nor have the post-70s' hunger for materials. In work, they fully take happiness as orientation, pay attention to individual realization, advocate freedom and equality, dislike brainwashing and educating infusion, and refuse cold number-based evaluation. As for them, the temptation from money and position and the threat from punishments are just like iron-crown spell with fault and have slight effect, and even cause misfortune.

Faced with such group, it is better for enterprise managers to change the way of thinking and use the ways and words of new generation to realize their goal rather than issue orders. The language of games is the new generation's collective memory and it can most stimulate sense of identity; the core concept of gamification thinking is to blend symbol system related to games into "non-game" management field, and explore the clues for new generation staff management from a brand-new perspective.

\section{To actively challenge barriers}

The great philosopher Bernard Suits defined the game as follows: playing game is a behavior that people are willing to attempt to overcome various kinds of unnecessary barriers. In a word, the definition explains the reason why the games can bring human with power, award, and interest, and it also brings the first clue for new generation staff management for us: to actively challenge barriers.

However, compared to games, the reality is passive, such as Foxconn's "Paramilitary" Management. Foxconn doesn't provide bad food, but it requires that the staffs with long dinner time shall write a self-reflection; Foxconn's has training of world-class level, but it will give economic punishments for staffs who come to work late, leave early, or are absent from work. We all thirst for learning, perfecting ourselves, and enjoying delicious food; however, quick enjoyment of delicious food and occupying rest time to participate in training become barriers. The above-mentioned rigid system is a iron-crown spell on staffs' head which forces them to accept challenges. However, this management mode suffers great challenge while it meets new generation. The new generation staffs advocate freedom and seek for happiness, and they reject those cold orders, rules, and systems existing everywhere.

Faced with them, the enterprise managers shall learn from game designers, and encourage staffs to actively challenge barriers. In terms of this aspect. The cosmetic brand AFU on Taobao stands at the forefront. The staffs can make a bet for their own performance; some staffs require a massage card, and some staffs require an iphone 5s. As long as their performance is achieved, they can take the award they want; among so many "stakes", the award with highest value is even a Benz car. Certainly, the "gamble" is not the only skill. Take Foxconn as an example: it can hold "quickly and happily have a meal" game on a monthly basis, and the participating staffs can have a meal while they listen to Phoenix Legend, or have a meal while they chat with each other, or have a meal while they take photos of themselves to express feelings, or quietly taste the food and speak out the 
significance of food they eat to health, and the only standard is that you shall quickly and happily have a meal. This game can be even made as a television program, through which it is able to let Foxconn's staffs and social public feel and approve Foxconn’s efficiency culture.

\section{Role playing}

The art of games focuses on identity, role playing and other core principles. In the role-playing game World of Warcraft, the users determine their identity via selecting skills, association, customization of individual character (body feature, and clothes, etc.) and other ways; this kind of unique identity determination can let users experience the life of another identity and then let them indulged into games.

The new generation staffs are full of interests and imagination to life, and their own way of thinking is also an unrestrained and vigorous style, thus the poker-faced work is a great challenge for them. The role-playing games not only can activate their way of thinking and stimulate their imagination, but also can let them gradually show the behavior pattern the role they play has in role-playing process. Take HSTYLE as an example: each staff has a name of a flower from Compendium of Material Medica; each kind of flow has respective function; in daily work, those staffs are called with respective name of flower. Except for entertainment, this method also lets staffs unconsciously affected by name of flower and become full of vitality. Such kind of silent emotional appeal way is a good medicine to new generation staffs.

\section{To establish the link}

Human beings are a kind of extreme social creature, and most of happiness come from the beautiful time people spend with the loved, and there is no exception even for the most restrained people. We thirst for sharing experience, establishing link, and completing the things that all people regard as important. The game industry meets human's thirst for establishing the link with the society; in games, when necessary, we can establish the link with others at any time.

In many people's eyes, the new generation is a multi-dimensional mirror surface; however, there is one same point, that is, they are accustomed to the life of keeping playing cell phone and computer and the mutual communication becomes lesser and lesser in internet era. Those outstanding talents gradually become rich and mechanical, intelligent and stiff like computer. In Foxconn, it is very common that a person doesn't know the name of his or her roommate who has accompanied with him or her for one year; a cell phone is those workers' only entertainment equipment and the only media to communicate with the world beyond factory. Faced with this situation, the enterprises need to organize some interest groups. There are many interest groups in Google, such as meditation class, movie club, win-tasting club, and Salsa club; except for ensuring normal communication in work, those groups also let staffs cause resonance and find friends in sparetime life.

\section{Interesting failure}

M.L.N.D laboratory investigation team finds that the players become more excited under failure state than under success state while they play Super Monkey 2. What makes the failure in Super Monkey 2 become so interesting? In game design, when the players make a mistake, an interesting thing will happen immediately: the monkey falls into the air from the edge of ball groove in a rotating way. This animation makes failure become happiness, and the dancing monkey is an award. It let players laugh and makes failure become gorgeous, splendid, and interesting.

The new generation staffs are commonly only child, and they live in " $6+1$ " family since childhood. Their grandparents and parents all take good care of them, and they never know what is frustration, thus it is easy for them to develop a consciousness of ego and be unable to stand frustration. When they meet problems and difficulties, they always can't handle them in a positive way and they easily give themselves up as hopeless. If the situation is not serious, they may select job-hopping; if the situation is serious, they may select to commit suicide. It's better for enterprise managers not to frankly criticize them, and they can adopt "interesting failure" to encourage them in 
an indirect way. Then, what kind of failure can be gorgeous and encouraging? In fact, the trick is very easy, that is, "let them laugh"; through interesting failure, it is able to let them keep the hope of final success and keep the courage of continuous trials. Just like AFU essential oil, as for groups whose index is not completed, the managers will let the staffs propose punishment suggestions by themselves; for example, each person has a bottle of the most pungent pepper in Hainan, fermented bean curd with durian. It seems entertaining, but the essence is to inspire their fighting spirit.

\section{To decorate working environment}

The design of game scene refers to the modeling design of all things except for role modeling in the game. The scene metaphor is a kind of unconscious visual symbol and analogy and delivers the inner meaning which deepens the topic via modeling, and it plays an important role in game design process. As for the game Chinese Paladin, the things which attract players include scene setting, original painting, and music with ancient style except for moving story line. Similarly, a good working environment is also one of essential factors for enterprise development.

In pioneering work, Huawei leaves a tradition called "mattress culture". It can be said that Huawei's "mattress culture" is the foundation for Huawei to win success, and it is also the symbol of Huawei spirit. I don't object to Huawei’s "mattress culture” and "striving culture; however, does the "mattress culture" certainly require to place a mattress under developers' bottom of steel cabinet or office table? Let's see the office of Google that all staffs in the world long for: the slide and slider are set downstairs and upstairs, the staffs can take electric skateboard or toy car to come and go to the office, let alone football on desk, billiard table, various kinds of video games, piano, table tennis tables, fitness center, and other entertainment facilities. Huawei's staffs are a batch of very excellent young people; they are wise and diligent with bigger ambition than their father generation. I believe that their view of value doesn't conflict with Huawei culture; however, they grow up in an era with prosperous economy and stable political situation; when they feel tried, please don't give them the treatment only existing in 1980s - making a bed on the floor in a house full of radiation.

Actually, the arrangement of working environment doesn't need to be like that in Google, and the slight decoration can let staffs find interests and warmness in work. Huawei can set a small rest room near office and laboratory, even though there are only several beds and green potted plants in the rest room. Foxconn can set an "expression wall” in the workshop, take photos of staffs' photos while they are working at random and paste those photos on "expression wall", and attach some encouraging words according to staffs" expression. Those words can be "you are great, for you are so happy!”, or "be proud, for your work lights human's future!” to help staffs to arouse positive emotion.

With the change of times, people are also changing. The enterprise managers must remind themselves of consciously catching up with young people's feet while they consciously catch up with the feet of the times at any time, for the future belongs to those young people.

\section{References}

[1] Dai Ting: Several Thoughts on New Generation Staff Management [J], Human Resource Management, 2014 (04).

[2] Xia Qing, Li Hongyan: Research on New Generation Staff Dimission Management Based on Job-embedded Theory [J], Science \& Technology and Economy, 2014 (01)

[3] Tao Xiaoxia: Research on Problems and Methods of Human Resource Management of New Generation Staffs [J], Manager Journal, 2014(02).

[4] You Jia, Sun Yuchun: Chinese New Generation Staffs and Their Management [J], Journal of Wuxi Institute of Technology, 2012 (03)

[5] Santiago - Velasquez: The Power of Gamification,

[J/OL].http://www.ebusinessreview.cn/articledetail-232765.html,2014.02.28

[6] Santiago • Velasquez: The Power of Gamification,

[J/OL].http://www.ebusinessreview.cn/articledetail-232765.html,2014.02.28 